\title{
What is Capital?
}

\section{Economists and sociologists have changed its meaning - Should it be changed back?}

\author{
Geoffrey M. Hodgson \\ Draft of 15 March 2014 \\ Hertfordshire Business School, University of Hertfordshire, Hatfield, Hertfordshire AL10 9AB, UK \\ www.geoffrey-hodgson.info \\ g.m.hodgson@herts.ac.uk
}

KEY WORDS: capital, money, finance, collateral, human capital, social capital

JEL classifications: B12, B13, B26, D24

\begin{abstract}
This article traces the historical usages of the term capital and the explosion of different types of supposed 'capital' in the twentieth century, including 'human capital' and 'social capital'. In medieval and early modern times, capital meant money investable or invested in business. This meaning persists in business circles today. In contrast, Adam Smith treated physical assets, machines and people as 'capital' and this different usage has dominated economics since. The pre-Smithian meaning referred to money or other saleable assets that could be used as collateral. This article questions the change in meaning by economists and sociologists, and highlights the importance of collateralisable property for capitalism. 'Human capital' can only be collateral if the humans involved are slaves. 'Social capital' can never be used as collateral and it is not even owned. These important issues are masked by the broadened notion of 'capital'. Given the conceptual problems involved, economists and sociologists should consider returning to the pre-Smithian and surviving business usage of the term.
\end{abstract}




\title{
What is Capital?
}

\section{Economists and sociologists have changed its meaning - Should it be changed back?}

\author{
Geoffrey M. Hodgson
}

'The question is', said Alice, 'whether you can make words mean so many different things.'

Lewis Carroll, Through the Looking Glass (1871)

How complete the divorce is between the experience of daily life and the teaching of the economists can best be seen by reading, for example, Marshall's chapter on capital, with its complicated divisions into national capital, social capital, personal capital, etc.. Every banker and every commercial man knows that there is only one kind of capital, and that is money. Every commercial and financial transaction is based on the truth of this proposition, every balance sheet is made out in this wellestablished fact. And yet every economist bases his teaching on the hypothesis that capital is not money.

Alfred Mitchell Innes (1914)

It might reasonably be presumed that to understand capitalism we must understand capital. ${ }^{1}$ But economists have long shifted the meaning of the word, and gradually widened its application. Sociologists have also contributed to its enlargement of meaning. No longer does it have any connection with any specific mode of production. In some of its conjunctions it inspires ambitious empirical research programmes, which unfortunately exhibit a congenital difficulty agreeing on what it is that they are trying to measure. We must consider what happened, and appraise the consequences for our understanding.

\footnotetext{
1 The author thanks Rutger Claassen, Frank Currie, Anne-Claire Hoyng, Klaus Nielsen, Ugo Pagano, Richard Van Den Berg, and four anonymous referees for their responses to an earlier draft. Although some of them questioned the desirability of a return to the original definition, their comments were very useful. In quotations herein, all emphases are in the original texts.
} 
It would be important to explain why the term changed its meaning, but that is a huge task, far beyond the scope of this paper. As well as the changing socio-economic context, such an account would have to examine the changes within, and rivalry between, the disciplines of economics and sociology. Instead, the main task of the paper is to note some key changes and extensions of meaning, and to consider their analytic implications.

The first section of this essay locates important milestones in the historical evolution of the word capital. The second section addresses the broadening of the term in the notion of 'human capital'. The third section lists some other extensions of the capital concept. The fourth section addresses 'social capital' at length. The fifth section draws the threads together and compares the merits and demerits of different definitions.

\section{A brief history of the c-word}

In the beginning, capital referred to head-counts of cattle. But in ancient Greece and Rome the word took a broader meaning, often referring to wealth in general. But there is no need for the c-word if the w-word means the same. Over eight hundred years ago the word capital acquired a more specific meaning, which has endured (except within economics and sociology) to this day.

Fernand Braudel (1982, pp. 232-33) pointed out in his Civilization and Capitalism that the word capitale was in use in Italy in 1211 and is found from 1283 'in the sense of the capital assets of a trading firm'. The word gradually came to mean the 'money capital of a firm or of a merchant' and spread through Western Europe.

In England in the sixteenth century the word retained its Italian and monetary meaning and was used by business firms in their accounting practices. Hence in 1569 one James Peele wrote on 'the art of Italian merchants accounts', described 'an inventorie' of 'all thinges ... apperteyninge to trade of merchaundise', and urged a businessman to 'accompte for his proper stocke or capitall’ (Cannan 1921, p. 471). Irving Fisher (1904, p. 392) quoted an Italian source of 1612 that had capital as a principal advanced as a quantity of money and a French source of 1694 that referred to capital as the principal of a debt. In England in 1635 Richard Dafforne in a book on accounting instructed his readers to 'booke the capitall which each partner of a joint company promiseth to bring in' (Cannan 1921, p. 471). The 1697 Bank of England Act of Parliament speaks of the 'common' capital and 'principal' stock of the company and 'the said capital stock' (Cannan 1921, p. 473).

Fisher (1904, p. 393) cited English sources of 1730, 1750 and 1759 that all define capital as a sum of money advanced by a trading company or 'the money which a merchant first brings into trade on his own account'. According to Edwin Cannan (1921, p. 475) the following entry appears in 1751 in Postlethwayt's influential Universal Dictionary of Trade and Commerce:

CAPITAL, amongst merchants, bankers, and traders, signifies the sum of money which individuals bring to make up the common stock of a partnership when it is first formed. It is also said of the stock which a merchant at first puts into trade, for his account. It signifies likewise the fund of a trading company or corporation, in which sense the word stock is generally added to it.

Accordingly, from Italy from the thirteenth century to Britain in the eighteenth, the word capital was mostly used in the sense of the money advanced by owners or shareholders to establish a business. 
But we can also find a second meaning, referring to a stock of goods, or even wealth in general. Frank Fetter (1930, p. 187) pointed out that Randle Cotgrave, in his Dictionarie in 1611 defined capital as 'wealth, worth; a stocke, a man's principall, or chiefe, substance'. Fetter commented: 'Here the idea of 'worth', implying a valuation, is thoroughly mixed with that of substance, no doubt in the sense of material things in possession. 'Capital' thus used is a superfluous and confusing synonym of wealth, goods and stock'. But the evidence suggests that as late as the eighteenth century the monetary meaning dominated its secondary use as a 'superfluous and confusing' synonym of wealth.

Then entered Adam Smith, and henceforth among economists the word changed its meaning. It is not necessary here to go into the influences upon Smith, including AnneRobert-Jacques Turgot and the Physiocrats. Crucially his vision of rising capitalism was of the amassment of things, produced and rearranged by labour. The opening preoccupation of The Nature and Causes of the Wealth of Nations is the division of labour and the increasing productivity of physical things. The 'nature' of wealth was physical stuff, typically produced by other stuff. Money did not fit readily into this scheme, unless it was treated as silver or gold, so that it too became a thing with intrinsic value, produced by labour. Capital became physical stuff. Smith wrote in several places in this book of 'stock' and 'capital stock' and he applied these terms to both money and goods. Eventually he considered these terms in more depth. For Smith (1976, p. 282) 'fixed capital, of which the characteristic is, that it affords a revenue or profit without circulating or changing masters' included machines, buildings, land and 'the acquired and useful abilities' of individuals. Smith continued:

The acquisition of such talents, by the maintenance of the acquirer during his education, study, or apprenticeship, always costs a real expense, which is a capital fixed and realized, as it were, in his person. Those talents, as they make a part of his fortune, so do they likewise that of the society to which he belongs. The improved dexterity of a workman may be considered in the same light as a machine or instrument of trade which facilitates and abridges labour, and which, though it costs a certain expense, repays that expense with a profit.

Although Smith did not use the term 'human capital', this is a major source of the idea that the term capital applies to people as well as things. By extending the notion of capital to people and their labour, Smith changed its meaning to a productive resource, rather than money or money-values. Cannan (1921, p. 480) commented on the above words from Smith:

This indicates a very serious departure from the conception of capital which had hitherto prevailed. Instead of making the capital a sum of money which is to be invested, or which has been invested in certain things, Smith makes it the things themselves. Instead of being a sum of money expended on the acquisition of stock, it is part of the stock itself. But the change is not pointed out to the reader in any way ...

For economics this shift of meaning was seminal. The term capital acquired the twin and often mutually confused meanings of money and productive goods, but often with the accent on the latter. Smith also hinted that labour power was also a form of capital, but that particular extension did not become widespread until the twentieth century.

Although most economists followed Smith and relegated the monetary meaning, they still could not agree on the precise definition of capital. Nassau W. Senior (1836, p. 156) wrote: 'Economists are agreed that whatever gives a profit is properly termed capital.' But the agreement was illusory. John Stuart Mill (1848, ch. 3) defined capital as the 'accumulated stock of the produce of labour'. With Senior, capital produces profit, but with Mill it is anything that is produced and accumulated. 
Marx had the insight that capitalism was a historically specific system, where money had moved from a medium for the exchange of commodities $(\mathrm{C}-\mathrm{M}-\mathrm{C})$ to the supreme goal of production and exchange (M-C-M'), where $\mathrm{M}^{\prime}$ is greater than $\mathrm{M}$. Money capital thus became the driving force of the system. But otherwise Marx did not try to reverse Smith's shift to a non-monetary meaning. He argued that the means of production become capital when they become means of exploitation of the workers. He wanted capital to refer to the central forms and driving processes in capitalism, including class exploitation and the production of value. Hence Marx (1976a, p. 933) quipped that 'capital is not a thing, but a social relation between persons, established by the instrumentality of things.' Similarly, in his chapter criticizing 'the trinity formula' of 'capital, land, labour' in classical economics, Marx (1981, p. 953) argued:

But capital is not a thing, it is a definite relation of production pertaining to a particular historical social formation, which simply takes the form of a thing and gives this thing a specific social character. Capital is not the sum of the material and produced means of production. Capital ... is the means of production monopolised by a particular section of society, the products and conditions of activity of labour-power ...

Marx's addition of social relations reinstated capital as a historically specific phenomenon. But this remained remote from the everyday meaning of capital as money invested in production. Marx was still tied to the classical vision of production in terms of physical entities and forces. Consequently, his discourse switched to and fro among relational, processual, physical and other incompatible meanings (Ingham 2004, pp. 61-3). Following earlier authors, he divided capital into 'fixed' and 'variable' forms, referring respectively to tangible productive resources such as machines, and to labour power.

Within the German historical school there were very different usages of the term. Wilhelm Roscher (1843) followed Smith and Senior and described all productive resources as Kapital. Karl Knies (1885, pp. 40-42) narrowed the definition to 'economic goods'. By contrast, Werner Sombart (1902, vol. 2, p. 129) recognized that capital is a phenomenon found in specific historical epochs and returned to its pre-Smithian meaning by defining it as 'the sum of exchange value which serves as the working basis of a capitalist enterprise'. But this was an exceptional statement.

Max Weber's position was similar to that of Sombart. In his Economy and Society - which was unpublished in his lifetime - Weber (1968, vol. 1, p. 91) wrote that "Capital" is the money value of the means of profit-making available to the enterprise at the balancing of the books'. Although Weber (1968, vol. 1, p. 94) also used the term 'capital goods', he saw them as 'all such goods as are administrated on the basis of capital accounting.' For Weber, 'capital' was expressed in monetary units in an era of rational accounting on the basis of monetary measurement.

The Austrian school economist Eugen von Böhm-Bawerk devoted an entire work to capital. For him, the problem of defining capital was intimately connected with the explanation of the interest rate and its magnitude. For Böhm-Bawerk (1890, p. 6)

capital signifies a complex of produced means of acquisition - that is, a complex of goods that originate in a previous process of production, and are destined, not for immediate consumption, but to serve as means of acquiring further goods.

There is no mention of money here. The focus is on physical goods that are used to produce more goods. Having demoted money, Böhm-Bawerk established a productivity theory of interest. 
Worried about the conflation of money with material products, John Bates Clark (1888) made a distinction between 'pure capital' and 'capital goods'. The latter term became widely used, but 'pure capital' referred rather vaguely to the value of the goods termed 'capital', or the fund of value somehow resident in them, and was not widely adopted. Despite Clark's attempts, 'capital' took a double meaning of money or goods. Hence Irving Fisher (1896, $1897,1904,1906)$ influentially and more broadly defining capital as any 'material' entity that produces a flow of income over time. Fisher, in contrast to Clark, regarded people as capital. He made explicit what was implicit in Smith's Wealth of Nations.

This broadened notion of capital met objections. In a work that appeared originally in 1894, John A. Hobson (1926, p. 26) noted that economists disputed the meaning of capital, while 'ignoring the clear and fairly constant meaning the term actually possesses in the business world around them.' Hobson pointed out that in the 'business world' capital meant 'money or the control of money, sometimes called credit' or 'all forms of marketable matter which embody labour.'2

Thorstein Veblen (1892, 1908a, 1908b, 1908c, 1908d) criticised Clark, Böhm-Bawerk and Irving Fisher. Echoing Marx, Veblen pointed to the failures of economists to associate capital specifically with the modern mode of production. But diverging from Marx and many others, Veblen argued that the sources of wealth were not simply material instruments combined with labour, but 'intangible assets' or 'immaterial wealth' including the common know-how in the community. In his critique of Clark, Veblen (1908a, pp. 162-3) wrote:

In current usage, in the business community, 'capital' is a pecuniary concept, of course, and is not definable in mechanical terms; but Mr. Clark, true to the hedonistic taxonomy, sticks by the test of mechanical demarcation and draws the lines of his category on physical grounds; whereby it happens that any pecuniary conception of capital is out of the question. Intangible assets, or immaterial wealth, have no place in the theory ... [Instead there is a] conception of capital, as a physically 'abiding entity' constituted by the succession of productive goods that make up the industrial equipment ...

Veblen underlined the everyday business definition of capital. He also highlighted the incongruity between the notion of capital as a physical substance and the real-world cycles of boom and bust, driven by market sentiment and leading to the expansion and destruction of financial assets. Veblen (1908a, pp. 164-6) noted the admission by economists that business crises 'destroy capital in part'. He continued:

The destruction in question is a matter of values; that is to say, a lowering of valuation, not in any appreciable degree a destruction of material goods. Taken as a physical aggregate, capital does not appreciably decrease through business disasters, but, taken as a fact of ownership and counted in standard units of value, it decreases. ... It would accordingly appear that the substantial core of all capital is immaterial wealth, and that the material objects which are formally the subject of the capitalist's ownership are, by comparison, a transient and adventitious matter.

Veblen (1908b, p. 117) thus concluded:

The failure of classical theory to give an intelligent account of credit and crises is in great part due to the habitual refusal of economists to recognize intangible assets, and $\mathrm{Mr}$.

\footnotetext{
2 The words 'which embody labour' are overly restrictive. If someone purchases an uncultivated wilderness and uses this asset as collateral, then the wilderness could be regarded as capital - in business parlance - although it is largely untouched by labour.
} 
Fisher's argument is, in effect, an accentuation of this ancient infirmity of the classical theory.

But Veblen's critique was inhibited by his own conception of production as a largely technical and physical engineering process, resting 'chiefly on the physical conditions of human life' that should be understood in terms of 'Physics and the other material sciences' (Veblen 1901a, p. 205), where the structures of human organization and motivation were downplayed. He thus retained part of the reigning physical story. Instead of denying the notion of capital as material, he added immaterial assets. But can capital be understood as a mixture of the two types of asset - the material and immaterial? ${ }^{3}$

Despite the efforts of economists to the contrary, elsewhere in business and financial circles the term capital retained its monetary meaning, throughout the nineteenth century and beyond. ${ }^{4}$ For example, the relevant entry in James A. H. Murray's (1893, p. 98) New English Dictionary on Historical Principles, saw 'capital' as 'pertaining to the original funds of a trader, company, or corporation; principal; hence, serving as a basis for financial and other operations.' Similarly, Alfred Mitchell Innes (1914, p. 152) noted: 'Every banker and every commercial man knows that there is only one kind of capital, and that is money.' Alfred Marshall (1920, pp. 66-7) made a similar acknowledgement in his Principles:

the language of the market-place commonly regards a man's capital as that part of his wealth which he devotes to acquiring an income in the form of money; ... This definition of capital from the business point of view is firmly established in ordinary usage ...

But Marshall (1920, p. 76) went on to redefine capital 'in harmony with the common practice of economists', which for him meant the trinity of land, labour and capital as factors of production. In the end, Marshall rejected the business usage; he stood with Smith and subsequent economists, rather than with the heterodox minority of economist critics.

Moving further into the twentieth century, the American economist Fetter - who was influenced by both Austrian economics and the original institutionalism - was one of the few to attempt to restore an earlier meaning. Fetter (1927, p. 156) saw the danger in the widening of the capital concept:

Capital is essentially an individual acquisitive, financial, investment ownership concept. It is not coextensive with wealth as physical objects, but rather with legal rights as claims to uses and incomes. It is or should be a concept relating unequivocally to private property and to the existing price system.

Fetter (1930, p. 190) insisted that capital is both a monetary and a historically specific phenomenon:

Capital is defined as a conception of individual riches having real meaning only within the price system and the market where it originated, and developing with the spread of the financial calculus in business practice.

\footnotetext{
3 Joan Robinson (1979) rediscovered Veblen's critique of Clark’s capital concept during the Cambridge capital controversies, which had been largely stimulated by the work of Sraffa (1960). Following Veblen, the Cambridge (UK) side of the debate insisted that capital as finance has been confused with capital goods. But other important features of Veblen's argument were overlooked.

${ }^{4}$ Even to this day, numerous dictionaries highlight the monetary and business meaning. For example, the Oxford English Dictionary defines capital as 'wealth in the form of money or other assets owned by a person or organization or available for a purpose such as starting a company or investing.'
} 
Within a few years another major capital debate had erupted within economics, this time between Friedrich A. Hayek (1934, 1935b, 1936) and Frank H. Knight (1934, 1935). Like J. B. Clark, Knight saw capital a fund of value which is malleable, and perpetual. For him, the rate of interest was determined entirely by the marginal productivity of capital goods, without reference to time preference. In contrast, Hayek followed Böhm-Bawerk and emphasized the heterogeneity of different capital investments with respect to their 'roundaboutness' and period of production. But Hayek rejected Böhm-Bawerk's subsistence-fund theory of the interest rate (Valiente 1980, Ahmad 1991, Cohen 2003).

What are interesting in this debate are not only the points of disagreement but also those of communality. Both Hayek and Knight argued within an equilibrium framework, while also hinting at its limitations. Neither saw capital as money. Both attempted to force round matters of finance were forced into the square holes of the technical structure of production. By contrast, Joseph A. Schumpeter (1954, pp. 322-3) insisted that the term capital should be applied to financial assets alone: ${ }^{5}$

The word Capital had been part of legal and business terminology long before economists found employment for it. With the Roman jurists and their successors, it denoted the 'principal' of a loan as distinguished from interest and other accessory claims of the lender. In obvious relation with this, it later came to denote the sums of money or their equivalents brought by partners into a partnership or company, the sum total of a firm's assets, and the like. Thus the concept was essentially monetary, meaning either actual money, or claims to money, or some goods evaluated in money. ... What a mass of confused, futile, and downright silly controversies it would have saved us, if economists had had the sense to stick to those monetary and accounting meanings of the term instead of trying to 'deepen' them!

This advice was not followed by economists. Notably, the Cambridge capital controversy of the 1960s and 1970s avoided the issue raised by Schumpeter and others. Both sides of the Cambridge controversy treated capital as physical rather than essentially financial, with Cambridge UK insisting on the heterogeneity of capital goods and the problem of their measurement and aggregation (Sraffa 1960, Harcourt 1972, Robinson 1979, Cohen and Harcourt 2003). The rate of profit was conflated with the rate of interest. Money and finance were much left out of the picture.

If Schumpeter, preceded by Hobson, Sombart, Weber, Mitchell Innes, and Fetter, are broadly right on this question, then economists have subverted a central concept. Their inability to deal adequately with capital derives in part from a social ontology that focused on the possession of physical objects, and in part from a reluctance to treat a core notion such as capital as historically specific, under the illusion that economics is the study of universal and ahistorical laws (Hodgson 2001). The German historical school critiqued ahistorical analyses. It was no accident that Sombart was a member of this school, and Schumpeter was deeply influenced by them (Streissler 1994, Ebner 2000, Michaelides and Milios 2009). Their key ideas were also available to Mitchell Innes and Fetter.

What then is capital? There are two prominent options. We could follow the post-Smith trend in economics and sociology and regard capital as any relatively durable thing or attribute that leads to the satisfaction of wants. According to this definition, capital has existed

\footnotetext{
5 Along the same lines, Schumpeter (1956, p. 174) wrote in 1917: "the capital market is the same as the phenomenon that practice describes as the money market. There is no other capital market.”
} 
since the dawn of humanity, and it is not confined to any specific mode of production. Marxism offers a variant on this first definition by narrowing capital to productive factors under circumstances where workers are employees and do not own the material means of production.

A second option is to follow Hobson, Sombart, Weber, Mitchell Innes, Fetter, and Schumpeter and return to the meaning of capital that emerged in Europe by the thirteenth century in the context of trading and investment. Capital is then defined as a fund of money to be invested by a person or firm in some enterprise. It can also refer to the money-value of tangible and intangible assets owned by the person or firm, which in principle can be used as collateral, and serve to buy or hire resources to produce goods or services for commodity exchange. In both cases, capital is measured as an amount of money. If it refers to the money value of other owned assets, then these can be used as collateral for money loans. Capital is money, or the realizable money-value of owned and collateralisable property. Contrary to Smith and his successors, neither wages nor wage labour can be capital - neither can act as collateral. Capital involves social relations, and social institutions such as money and private property, but contrary to Marx, it does not necessarily involve the employment of workers by capitalists.

\section{Can humans be capital?}

We have seen that Smith regarded labour and skill as forms of capital, but he did not use the term 'human capital'. When did the idea of labour skills as capital become prevalent and when did the term 'human capital' emerge? We have to consider both the history of the term and the history of the ideas behind it. ${ }^{6}$

The first appearance of the term 'human capital' long pre-dates its twentieth-century exponents. Sir William Cornwallis Harris (1807-1848) was an officer in the army of the East India Company. He travelled in Africa and India and was a prolific writer. He wrote a 'Report to the Secretary of the Bombay Government' on the African slave-trade (Harris 1842). Extracts from this report were published on December 2, 1844 in the British pro-development and anti-slavery journal The Friend of the Africans. In his report Harris addressed 'African commerce' and pointed to the underdevelopment of its industry and manufactures. Harris continued: 'Few, if any, of the commodities which she barters with other countries for the rude and limited supplies that she seeks are the production of human capital, labour, or industry.' This is the first known use of the term 'human capital'. Its precise meaning here is unclear, particularly as the terms 'human capital' and 'labour' are adjacent. Ruling out the possibility of needless repetition by an accomplished writer, this suggests that for Harris these terms did not mean the same thing. Especially given the context, it is possible that by 'human capital' Harris meant slaves.

There is a reason for this interpretation. As pointed out above, among non-economists for centuries capital has had the meaning of monetary investment in fixed assets that are purchased and used in, but unconsumed by, production. This commonplace usage excludes raw materials and hired labour. But a slave, like a machine, is retained by its owner. In this sense, a slave - but not a wage labourer - can be capital. But when 38 years later the term 'human capital' appeared again, there was no allusion to slavery (Donisthorpe 1880, p. 28). Nevertheless, five years earlier, the Scottish-born merchant, historian, statistician and

\footnotetext{
${ }^{6}$ Klaes (2001) made a strong argument in favour of investigations into the history of the use of key terms in discourse, in addition to the history of the ideas that such terms may represent.
} 
Australian politician William Westgarth (1875, pp. 23, 64) had written in his pamphlet on the Science of Capital and Money:

labour can be wealth or capital ... only when it is bonded, and thus rendered a definite subject of exchangeable value. It is in this sense that a slave is true capital, but not a free man. Labour brings wealth into being, but excepting in any of the various bonded forms I shall have occasion to allude to, it is not itself wealth. ... A slave is a definite marketable subject, and is capital, but a free agent is not.

Westgarth (1875, p. 65) was not supporting slavery but protesting against the application of the term capital to 'the mere labour possibility or labour capacity of a country, or of any of its people.' Later in this section I shall argue that the issue of slavery is relevant in the discussion of the notion of human capital, but for reasons that are different from and more robust than those provided by Westgarth. ${ }^{7}$

The term 'human capital' makes its first appearance in a prominent journal of economics in an article by Irving Fisher (1897), who proposed that all factors of production, including machines, land and labour, should be described as capital. Veblen (1908b, p. 115) was one of the few to object to this extension of meaning:

A serviceable definition of capital, one that shall answer to the concept as it is found in practice in the habits of thought of business men, will not include persons. ... And as for a business man's capitalizing other persons, the law does not allow it, even in the form of peonage.

Veblen thus alluded to the illegality of enslavement, implicit in the treatment of persons as capital. But otherwise the term 'human capital' met little opposition and became commonplace after the seminal works of Theodore W. Schultz $(1960,1971)$ and Gary Becker (1964). 'Human capital' therein meant a factor of production, among others. Its magnitude was enhanced by education and training. A key objective for economists was to estimate its value so that quantities of this labour-stuff could be put into a production function alongside other inputs, in order to 'explain' the magnitude of output, the contribution of education, the demand for education, and so on. ${ }^{8}$

We now turn from the history of the term to the lineage some of the key ideas behind it, particularly as developed in the research program of Schultz and Becker. An article by B. F. Kiker (1966) considered these precedents. He explained that in economics there have long been broadly two approaches to the valuation of human beings. One is to estimate the cost of producing an individual in terms of care, nutrition and so on. The other is to evaluate an individual in terms of all expected future earnings. As Kiker documented, these ideas have a long history.

Sir William Petty (1690) devised a method of calculating the money value of human beings, and hence the cost of life lost through diseases and wars. His method was to estimate the future wage bill in perpetuity at the market interest rate. But he did not describe labour as capital. His objectives were different from those of Schultz and Becker. Petty wished to

\footnotetext{
7 Westgarth (1875, p. 28) wrote: 'We must deal in economics with definite things. The unengaged labour power of a free agent is altogether an indefinite quantity, and quite outside of economic science.' But when labour became bonded by agreement or enslavement then it became 'a definite subject to deal with.' He adopted a physical or mechanistic view of money and denied that credit was money or capital.

${ }^{8}$ Note the classic critical review of this research program by Blaug (1976).
} 
determine the magnitude national wealth, estimate the benefits of employing idle labour, and provide a framework for establishing just and efficient taxation.

Kiker (1966, p. 482) then addressed what he described as 'the first truly scientific procedure' for estimating human capital. This he found in the work of William Farr (1853), who was primarily concerned with the matter of taxation. Farr argued that the present value of a person's net future earnings, which he defined as earnings less living expenses, represented wealth in the same way as did physical property and should be similarly taxed. This method of capitalizing a future net income flow was later developed and enshrined within economics by Fisher (1907). But unlike Fisher, Farr did not use the term 'human capital' and did not imply that labour as capital. Instead, for him 'the property inherent in a man' is 'Inherent Property’ (Farr 1853, p. 2). Kiker (ibid.) then remarked:

Farr's work ... suggested that since human beings are productive they should be regarded and taxed as capital. Since this would oblige people to pay tax on wealth they do not have to hand, it could lead to absurd results.

Let us probe Kiker's claim that the 'capital' valuation of labour-power could lead to 'absurd results' because workers do not have this wealth 'to hand'. It is also possible that the owner of a factory and its machinery may not have 'to hand' money representing the estimated value of the owned assets. Yet Kiker suggested that the capitalist is advantaged in this respect, compared to the worker. Kiker is right, but he does not give the reason why. Both the capitalist and the worker own wealth in Farr's sense, in the form of the discounted present value of the future income stream of their assets. The unspoken matter is that the capitalist can borrow money on the basis of the collateral in her owned factories or machines, but the worker has no such collateral.

Why is it unfeasible for the worker to go to the bank and borrow on similar grounds as the capitalist? A bank may offer a limited loan on the basis of expected future earnings (as with some student bursary schemes), but such offers will be relatively limited unless the worker can offer collateral. For a loan approaching the present value of the future income stream, the banker would demand collateral to cover the risk of non-payment or of the future income being below expectations. The purpose of collateral is to safeguard the lender: if the loan is not repaid as agreed, then the banker can sue the defaulter, and force the sale or gain possession of collateralized assets if necessary. The crucial point is that factories and machines can serve as collateral on a loan, but the labour power of a wage-worker cannot. When the worker defaults on loan repayments she cannot sell the 'wealth' constituted by her future earnings, unless she sells herself into slavery. To avoid the 'absurd' outcome noted by Kiker, and restore the symmetry between the 'wealth' of the capitalist and the employee, the worker would have to be able to borrow money using her value as a slave as collateral. If the worker defaults on her repayments then she can be sold on the slave market to recover the debt. The symmetry in several respects would be restored, albeit at the cost of the worker's freedom. But equality under the law blocks this option. This point was briefly acknowledged by one of the early human capital theorists. In a rare visitation of this issue, Schultz (1972, p. 7) emphasized that

human capital has some distinctive attributes. Whatever its form, it cannot be bought and sold except where men are slaves. Whereas material capital has the legal status of property, human capital is not 'protected' by this legal mantle, slavery aside. For example, the freedom of choice in acquiring educational capital is subject to the difference in the legal status of human rights and that of property. Since a person cannot indenture himself or enter into a contract that would encumber his human rights, it 
follows that in the case of a loan to a student for his education, the lender's property right in the capital funds that he transfers to the student cannot be covered by a mortgage on the student.

Also Paul Samuelson (1976, p. 52) wrote in his famous textbook:

Interestingly enough most of society's economic income cannot be capitalized into private property. Since slavery was abolished, human earning power is forbidden by law to be capitalized. A man is not even free to sell himself: he must rent himself at a wage.

But such statements are exceptional. Samuelson and Schultz got good marks for noting that labour power cannot be mortgaged, i.e. used as collateral. But they failed to note that the possibility of collateralization is a key part of the everyday usage of the word capital. If we can have 'human capital', then we have to find another word to describe collateralisable capital. But instead of dealing with these conceptual problems, the literature on 'human capital' moved on to address its own research program, oblivious to the conceptual limitations of treating 'human capital' alongside other 'capital' inputs as an array of arguments in a production function. The damage had been done.

There are two important lessons in this story. First, vital to the everyday meaning of the word capital, is either money or the realizable money value of an asset. Realizable money value means that the asset can be used as collateral for securing a loan. Capital is money or money value, and it is tied up with the capitalist system of debt.

Second, and consequently, it is a major error to apply the term capital in this sense to assets that are not money, do not have realizable money value, or only have a realizable money value under a non-capitalist economic system. Labour power comes in under the third option. Its full money value would be realizable under a system of slavery. Westgarth $(1875, \mathrm{p} .64)$ was right but for the wrong reasons: 'A slave is a definite marketable subject, and is capital, but a free agent is not.'

The reader may object that we can define words as we wish, and the common usage among economists of capital is that of any productive asset. Fair enough. But given the importance of understanding money, debt and collateralization for even an elementary appreciation of the nature of capitalism, it is important to acknowledge that the 'human capital' of a waged worker is of a very different nature from the 'capital' owned by a capitalist. Both are assets but - as long as slavery is prohibited - only one can act as collateral. This crucial distinction gets lost if we extend the usage of the word capital, at least without adding qualifying terms that preserve the vital monetary meaning and its association with collateral and debt. After Smith, economists changed their conceptual toolkit in a way that made key features of the rising capitalist order invisible to their theory. That conceptual blindness has to be rectified in some way.

Marshall freely acknowledged some of the differences between the selling of labour and the selling of goods. Marshall (1920, p. 569) noted that 'when a person sells his services, he has to present himself where they are delivered. It matters nothing to the seller of bricks whether they are to be used in building a palace or a sewer: but it matters a great deal to the seller of labour.' This is true and important. But Marshall failed to note that goods may be used as collateral, but the wage-labourer cannot mortgage his or her labour power. 
Marxists have also fallen short on this issue. ${ }^{9}$ While they have generally avoided the term 'human capital' they have done so because they also use the c-word to refer to a system of extracting surplus value from the workers, rather than to a mere input into the production process. But at the same time their own usage of the term 'capital', based on a downgrading of the legal phenomena of property, contract and debt, omits the key feature of monetary collateralization. ${ }^{10}$

To answer the question that heads this section, humans can be capital, but only when they are slaves. Marx sometimes misleadingly remarked that workers under capitalism were slaves (Marx and Engels 1989, p. 91), but in Capital he put a different view (Marx 1976, p. 271). Mainstream economists adopted the term 'human capital' nevertheless. Neither Marx nor mainstream economists accented collateralization, and the consequent crucial difference between the property of a capitalist and that of a worker.

\section{3. 'A plethora of capitals'}

If the word capital can apply to anything that helps production, then it can apply to a huge range of material and immaterial assets. ${ }^{11}$ 'Natural capital' appeared early on as an alternative term for land and mineral resources (Johnson 1909). But the flood came after the 1960s, prompted by the work by Schultz, Becker and others on 'human capital'. It also inundated sociology. As James N. Baron and Michael T. Hannan (1994, p. 1123) noted: 'a minor sociological industry' arose 'to construct sociological parallels to human capital', giving rise to 'a plethora of capitals'. In economics, sociology and related disciplines, this plethora now includes:

'natural capital' (Johnson 1909),

'health capital' (Grossman 1972),

'religious capital' (Azzi and Ehrenberg 1975),

'linguistic and cultural capital' and 'symbolic capital' (Bourdieu 1977),

'reputational capital' (Veljanovski and Whelan 1983),

'social capital' (Bourdieu 1986, Coleman 1988, 1990, Putnam 1995),

'organizational capital’ (Tomer 1987, Klein 1988),

'academic capital’ (Bourdieu 1988),

'cultural or consumption capital' (Becker and Murphy 1988),

'cognitive capital' (Rescher 1989),

'symbolic capital' (Bourdieu 1990),

'environmental capital’ (Hartwick 1991),

'self-command capital’ (Lindenberg 1993),

\footnotetext{
9 Nitzan and Bichler (2009) wrote repeatedly that "capital is power.” This is unsatisfactory, for several reasons. Power has a much longer history, so power cannot be the sole defining characteristic of capital. They also deploy a flawed definition of power as "confidence in obedience" (p. 17). It would imply that an over-confident individual, deluded by the extent of her powers, was in fact powerful. Powerful people often become megalomaniacs, but megalomania itself is not power. More plausibly, they also wrote that: "Capital is ... a capitalization of expected future earnings" (p. 211) and "the elements of corporate capitalization ... represent ... the power of a corporation's owners" (p. 8). They declared: “All capital is finance and only finance” (p. 262).

10 See Hodgson (2003, 2014) and Heinsohn and Steiger (2013) for discussions.

11 Very early Germanic ventures in this direction were Roscher's (1870, pp. 81-87) geistige Kapital (intellectual or spiritual capital) and the 1878 notion by Nietzsche (1996, p. 258) of Geist- und Willens-Kapital (capital of the spirit and will).
} 
'network capital' (Sik 1994),

'personal capital' (Dei Ottati 1994, Becker 1996),

'political, social and cultural capital' (Mouzelis 1995),

'intellectual capital' (Edvinsson and Malone 1997),

'resource capital and institutional capital' (Oliver 1997),

'spiritual capital' (Verter 2003),

'individual trust capital (relational capital)' (Castelfranchi et al. 2006),

'collective trust capital' (Castelfranchi et al. 2006),

'street capital' (Sandberg and Pedersen 2009) and even

'erotic capital' (Hakim 2011).

Given this burgeoning literature and so many different manifestations, one would have difficulty in identifying what enduring entity or property is not some variety of capital. Capital has now acquired the broad meaning of a stock or reserve of anything of social or economic significance. Everything has become capital.

Long divested of its monetary associations, economists had made it respectable to describe any unconsumed productive resource as capital. Now sociologists can earn academic reputations by discovering new forms of 'capital'. Instead of critiquing each of the above terms, the next section focuses on the most popular, namely the remarkable rise of research into 'social capital'. Several of the critical remarks that apply to this term apply to others on the above list.

\section{4. 'Social capital'}

The term 'social capital' is found in all three volumes of Marx's Capital and in Marshall's Principles (Marx 1976, 1978, 1981, Marshall 1920). But in these contexts it had a different meaning: it referred to national aggregates of productive assets or wealth. ${ }^{12}$ As Fetter (1927, p. 156) remarked on Marshall's usage: 'Social capital is but a mischievous name for national wealth.'

But a different meaning was established when the American social reformer Lyda J. Hanifan (1916, p. 130) defined 'social capital' as 'good will, fellowship, sympathy, and social intercourse among the individuals and families that make up a social unit'. ${ }^{13}$ This second meaning became widely adopted when French sociologist Pierre Bourdieu (1986), Chicago sociologist James Coleman (1988, 1990) and political scientist Robert Putnam (1995, 2000) used 'social capital' to describe social obligations, ties or networks that create social cohesion and may promote economic development. This idea has proved enormously popular with major institutions such as the World Bank and the International Monetary Fund. But to date there is no consensus among its advocates on a clear definition of the term. It is used to refer to multidimensional social attributes, such as frequencies of interaction in different contexts, participation levels in social organizations, level of trust, and so on.

There is no doubt that social relations, networks and trust have economic effects. Indeed social ties and social rules are necessary for any society and its economy to function. But a

\footnotetext{
12 The term "public capital” appeared early in the nineteenth century (Anonymous 1819) and occasionally thereafter, but then the term clearly referred to money in the hands of the public. It acquired the current physical meaning of public infrastructure much later.

13 Renan (1899) previously wrote: 'An heroic past, great men and true glory are the social capital on which the idea of a nation is based.'
} 
major issue of contention is whether they should be regarded as a form of capital. This is discussed later in this section.

Another question is whether anything new had been discovered beneath the label. Sociologists had long investigated the nature and effects of such phenomena as networks, organizations and trust, but this research was often depicted by critics as soft and secondary. Then two leading sociologists adopted the term and its usage took off. It had a hard-edged economic feel, while suitably underlining the importance of the social.

The term was so successful that it re-entered economics with its post-Bourdieu meaning. Economists had since the 1950s been worrying about their inability to account for much of economic growth using production functions with 'capital' and 'labour' as inputs. Their first reaction was to regard the unexplained residual as due to technological change. Then pioneering institutional economists such as Douglass North (1971) and Mancur Olson (1982) argued that different or changing institutions should also be taken into account.

In the desperate search for missing ingredients to help explain economic growth, the 'social capital' label worked wonders. It had connotations of yet another measurable substance that might be put into a production function, as long as the problems of its definition, heterogeneity and measurability could be overcome. Extraordinarily successful in both disciplines, it was a marketing triumph.

But 'social capital' shares problems of measurability with all other forms of capital, including 'human capital'. These were revealed when the Cambridge (UK) side in the capital debates established the significance of the heterogeneity of 'capital goods' (Sraffa 1960, Harcourt 1972, Robinson 1979, Cohen and Harcourt 2003).

Furthermore, the term 'social capital' has attracted the criticism of both mainstream and heterodox economists. ${ }^{14}$ But the problems inherent in the shift of meaning of 'capital' from money to things have been largely ignored. With the term 'social capital' these previous problems are greatly compounded. Consider some of the criticisms in more detail. Kenneth Arrow (1999, p. 4) wrote:

The term 'capital' implies three aspects: (a) extension in time; (b) deliberate sacrifice in the present for future benefit; and (c) alienability. The last is not true for human capital and not even entirely true for [irreversible] physical investment ... But it is especially (b) that fails. The essence of social networks is that they are built up for reasons other than their economic value to the participants ...

Arrow here attempted to set out three characteristics of capital and measure 'social capital' against them. While he rejected 'social capital', his critique is flawed. The first characteristic (a) clearly applies to social capital as well, so it is unhelpful. Misleadingly, he claimed that the third characteristic (c) of alienability does not apply to 'human capital'. He overlooked that 'human capital' can be sold when it consists of slaves. And his claim that some forms of physical investment cannot in principle be sold is perplexing. Many irreversible or immobile investments can indeed be sold.

Arrow mentioned the non-alienability (the inability to sell) 'social capital' but failed to give it sufficient weight. To do this he would also have to reject the concept of 'human capital', which is not generally alienable (at least with wage-labour). Failing to reject this too, he had

\footnotetext{
14 See Arrow (1999), Bowles (1999), Solow (1999), Baron, Field and Schuller (2000), Fine (2001), Knorringa and van Staveren (2007).
} 
to downgrade the importance of alienability. Instead he ended up stressing the second point (b) concerning 'deliberate sacrifice for future benefit'. Clearly, most of what is described as 'social capital' is not built up deliberately. But if a country were to follow the advice of the World Bank and others, and aim to build up its 'social capital' with an eye to improving national economic performance, then Arrow's formulation would suggest that it had also become a form of capital. His emphasis on the second criterion is unconvincing. He should have put more stress on the third, while abandoning the concepts of 'human' as well as 'social' capital.

Robert Solow (1999, p. 6) saw 'social capital' as 'an attempt to gain conviction from a bad analogy.' He then wrote:

Generically 'capital' stands for a stock of produced or natural factors of production that can be expected to yield productive services for some time. Originally anyone who talked about capital had in mind a stock of tangible, solid, often durable things such as buildings, machinery and inventories.

This additionally implies a rejection of the concept of 'human capital'. Labour power is neither generally 'tangible' nor 'solid'. Solow reverted to a physical concept of capital that has some resemblance to notions in Marx and Marshall, but his exclusion of labour or skill from the category of capital gives it an even narrower meaning than that of Smith. Solow (p. 9) concluded: 'I do not see how dressing this set of issues in the language and apparatus of capital theory helps much one way or the other.' But his criticisms were inadequate. By claiming that originally 'capital' for 'anyone' meant physical assets, Solow seemed unaware of its persistent meaning outside economics.

In his critique of 'social capital', Samuel Bowles (1999, p. 6) wrote:

'Capital' refers to a thing possessed by individuals; even a social isolate like Robinson

Crusoe had an axe and a fishing net. By contrast, the attributes said to make up social capital - such as trust, commitment to others, adhering to social norms and punishing those who violate them - describe relationships among people.

But even here there are problems. What is important about capital is not possession but legal rights of ownership: he seemed to conflate the two. He also created problems by overlooking the legal and financial institutions required to sustain capital, alongside an unhelpful reference to Robinson Crusoe. He rightly alluded to questions of alienability, but weakened their punch by treating capital as things. Bowles was right to state that 'social capital' concerns social relations. But he also needed to focus more specifically on the historically-specific social relations associated with 'capital', more narrowly defined.

Economists and sociologists have vastly widened the meaning of capital. Leading economists such as Arrow, Bowles and Solow thought that 'social capital' was a step too far. But Mitchell Innes, Fetter, Schumpeter and others argued more acutely that the problems with the over-stretched capital concept derive from the abandonment of its long-lasting (and stillcurrent) monetary meaning. These difficulties are compounded with the imprecise concept of 'social capital'. Unlike machines, land and slaves, it cannot be owned, borrowed, bought or sold. Consequently, it is difficult to give it a meaningful price. Crucially, because of its intrinsic elusiveness and the impossibility of owning or selling it, 'social capital' cannot be used as collateral in order to borrow money.

The broadened usages of the term 'capital' overlook the key differences. Partly because of unwarranted conflation of different public and academic meanings, policies designed to build up 'social capital' may employ a spurious methodology of measurability, and may incline 
with inadequate justification towards price-based or market instruments. Social scientists should consider returning to less glamorous but much more useful terms such as 'institutions', 'culture', 'networks', and 'trust'.

\section{Summary and possible conclusions}

Both classical and neoclassical economists adopted ontologies where economic value was seen as deriving from physical activities, substances or sensations, such as embodied labour time or utility (Mirowski 1989, Orléan 2011). ${ }^{15}$ Agents came in as possessors or controllers of these things or substances. More specific legal rights over property, such as the rights to alienate or use as collateral, were downplayed. Instead of money, or owned and alienable assets that are convertible into money, capital came to mean anything lasting, which contributes to the production of goods or services. With the exception of Marx, 'capital' was no longer regarded as a historically specific and monetary phenomenon, associated with the capitalist epoch.

Money confounds this classical and neoclassical picture. Money concerns mutual understandings and individual interactions, played out on a register of symbols or material representations (Searle 1995). According to the commonplace business view, capital is either money or the money value of alienable property. This view involves legal rights and institutions, as well as agent-object relations.

Prominent different usages of the word 'capital' and possible attributes of different forms of 'capital' are summarized in Table 1. The four kinds of 'capital' considered are (a) capital as money or collateral, (b) ‘capital goods', (c) 'human capital’, and (d) 'social capital'.

Each of these four kinds is considered in regard to five criteria: (1) Can its use-rights (i.e. usus or usus fructus rights) be owned or hired? (2) Has this form of capital a price formed in the market for capital of this type? (3) Can this kind of capital be used as collateral to borrow money? (4) Can this kind of capital be sold with all rights of ownership transferred to the purchaser? (5) Is the value of this kind of capital measurable? These five criteria are selfevidently important in economic terms, and reveal major differences between the different types of 'capital'.

15 André Orléan (2011, p. 12) wrote: "la valeur marchande n’est pas une substance ... qui préexiste aux échanges. Il faut plutôt la considérer comme une création sui generis des rapports marchands.” (Translation: "market value is not a substance ... that predates trade. Rather it must be considered as a sui generis creation of market relations.”) 


\begin{tabular}{|c|c|c|c|c|}
\hline & \multicolumn{4}{|c|}{ Types of 'Capital' } \\
\hline & $\begin{array}{l}\text { Capital (as finance } \\
\text { or collateral) }\end{array}$ & $\begin{array}{l}\text { 'Capital Goods’ } \\
\text { (as physical } \\
\text { factors of } \\
\text { production) }\end{array}$ & 'Human Capital' & 'Social Capital' \\
\hline $\begin{array}{l}\text { First prominent users } \\
\text { of the idea or concept }\end{array}$ & $\begin{array}{l}\text { Medieval Italian } \\
\text { capitalists }\end{array}$ & $\begin{array}{l}\text { A. Smith } \\
\text { had the idea }\end{array}$ & $\begin{array}{l}\text { A. Smith } \\
\text { had the idea }\end{array}$ & $\begin{array}{l}\text { L. Hanifan } \\
\text { had the idea and } \\
\text { used the term }\end{array}$ \\
\hline $\begin{array}{l}\text { Social scientists who } \\
\text { promoted the term in } \\
\text { the designated manner }\end{array}$ & $\begin{array}{l}\text { J. A. Hobson } \\
\text { W. Sombart } \\
\text { M. Weber } \\
\text { A. Mitchell Innes } \\
\text { J. A. Schumpeter }\end{array}$ & J. B. Clark & $\begin{array}{l}\text { I. Fisher } \\
\text { G. S. Becker } \\
\text { T. W. Schultz }\end{array}$ & $\begin{array}{l}\text { P. Bourdieu } \\
\text { J. Coleman }\end{array}$ \\
\hline $\begin{array}{l}\text { Can the use-rights be } \\
\text { owned or hired? }\end{array}$ & Yes & Yes & Yes & No \\
\hline Has it a market price? & Yes & $\begin{array}{l}\text { Yes - in many } \\
\text { cases }\end{array}$ & $\begin{array}{l}\text { Wage-labour } \\
\text { allows a price for } \\
\text { use-rights only }\end{array}$ & No \\
\hline $\begin{array}{l}\text { Can it be used as } \\
\text { collateral? }\end{array}$ & Yes & Yes & $\begin{array}{l}\text { No - except in the } \\
\text { case of slaves }\end{array}$ & No \\
\hline $\begin{array}{l}\text { Can it be bought or } \\
\text { sold (alienated)? }\end{array}$ & Yes & Yes & $\begin{array}{l}\text { No - except in the } \\
\text { case of slaves }\end{array}$ & No \\
\hline $\begin{array}{l}\text { Is it readily } \\
\text { measurable in the } \\
\text { aggregate? }\end{array}$ & Yes & $\begin{array}{l}\text { No - except by } \\
\text { assuming a list of } \\
\text { relevant prices }\end{array}$ & $\begin{array}{l}\text { No - except by } \\
\text { assuming a list of } \\
\text { relevant wages }\end{array}$ & No \\
\hline
\end{tabular}

Table 1. Meanings of 'Capital' and their Attributes

The table dramatizes the contrasts between different kinds of 'capital', with the most extreme divergence being between 'social capital' and money-oriented capital. The contrast between 'human capital' and money-oriented capital is also striking. Significant but less dramatic are the differences between 'capital goods' and money-oriented capital. Remarkably, the entire Cambridge capital controversy (Sraffa 1960, Harcourt 1972, Robinson 1979, Cohen and Harcourt 2003) focused in the lowest box in the 'capital goods' column. While mainstream economists had treated capital as a substance, the Cambridge (UK) critics emphasized the heterogeneity of 'capital goods'. Their value can be measured by assuming a price or other vector of evaluation, and then aggregating according to that metric. But because such a measure has to be assumed at the outset, there is no viable measure of 'capital goods' that is independent of distribution or prices. This is an important point, but it is confined to 
one single cell in the table. The Cambridge (UK) critics also pointed to the unwarranted conflation of capital goods with money-oriented capital, which had been previously criticized by Veblen (1908a, pp. 185-6; 1908d, pp. 121-2).

But Table 1 does not complete the argument. It reveals weaknesses in the concepts of 'human capital' and 'social capital'. Dealing with 'capital goods' is trickier, as it qualifies affirmatively on all but one criterion. The key question is what usage of the term capital is legitimate? Of course there is no strict rule here because there is no law against trying to make words mean anything we wish.

We have a choice. We can follow the trend in economics and sociology and regard capital as any relatively durable thing or attribute that leads to the satisfaction of wants. Marxism offers a variant on this first definition by narrowing capital to productive factors under circumstances where workers do not own the material means of production. A third option is to follow Hobson, Sombart, Weber, Mitchell Innes, Fetter, and Schumpeter and return to the meaning of capital that emerged in Europe by the thirteenth century in the context of trading and investment, and persists in business usage today. Capital is then defined as a fund of money to be invested in some enterprise.

Consider six reasons for confining the meaning of capital, to money investible in production, or to the money value of owned, alienable, collateralisable assets that are employed in production. This means rejecting the terms 'human capital' (except in relation to slavery) and 'social capital'. The term 'capital goods' can be retained only if its meaning is changed from a factor of production, to goods that that can be used as collateral. The reasons are as follows.

First, capitalism is arguably a historically specific type of system where capital plays a dominant role. Marx, Weber, Hobson, Sombart and Schumpeter all saw capitalism as existing from around the seventeenth or eighteenth century. All other forms of 'capital' have a much greater longevity. Much of what goes under descriptions of 'social capital' - such as networks and trust - can be found in the primates. If 'human capital' means any learned capacity for labour, then this would go back to adults teaching children to make fire. With 'capital goods' the use of stone tools by humanoids stretches back millions of years. By contrast, even if we regard the loans of the temple-banks of Mesopotamia as capital, then the history of moneyoriented capital is merely about five thousand years. We could even go further and confine capital to the second millennium AD, noting its emergence in some Italian city states. Then the life of capital is less than a one-thousandth of 'social capital', 'human capital' or 'capital goods'. If we consider its developed lifetime to begin in Britain around 1700, then there is an even greater contrast with its supposedly kindred concepts. Wherever the joints are carved, capital (defined in terms of money) is much more historically specific than its purported relatives, and hence is much more useful in identifying capital-ism.

Second, if we choose to allow capital to be used in more ways than its monetary meaning, and to apply to other phenomena, then we need another word to describe its important, commonplace, and historically relevant monetary form. Perhaps we might instead use the terms 'money capital' or 'finance capital'? But then we would have to describe the system as money-capitalism or finance-capitalism. Both would falsely allude to another more basic type of capitalism, when we are trying to describe the species as a whole. Alternatives such as 'collateralisable capital' are perhaps too ungainly. This leaves us with the more radical solution: to confine capital solely to its everyday monetary meaning.

Third, the conjunction of the word 'capital' to a large variety of very different phenomena has been at the cost of a large amount of relevant meaning. 'Social capital' overturns the 
commonplace usage of capital. Very serious problems remain with 'human capital'. Huge problems have been caused by the conflation of 'capital goods' with money-oriented capital. These problems arise with such extensions of meaning.

Fourth, all words bring their own baggage. Much of this baggage is ideological. Although good economists keep a sharp lookout for ideological biases, the wider public with which economists interact is less well trained. Theories get distorted into statements of ideology. Hence given the previous prominent designation of 'capital' as a pecuniary phenomenon, combined with the prevalence of an ideology regarding markets as the universal solution to economic and social problems, the promiscuous associations of 'capital' can give the impression that all political, cultural, social, cognitive and ecological phenomena can be valued and traded in monetary terms, and invested like finance capital. The inference may be drawn that everything labelled as 'capital' is tradable, and has a price. For example, terms such as 'environmental capital' or 'natural capital' may delude politicians and policy-makers that all environmental assets can be, and indeed need to be, valued properly in price terms. They then seek expert and well-paid economists to carry out the pecuniary evaluations. But giving something a price is not the same thing as establishing the possibility of ownership and alienability. There many things - like love, trust and honour - that cannot be readily traded, and do not have a meaningful or appropriate price (Fox 1974, Walzer 1983, Ellerman 1992, Satz 2010, Sandel 2012). At least in part, nature may become a money-valued object of ownership and a source of pecuniary gain. But seeking maximum profits is not necessarily the same thing as securing ecological sustainability (Krall and Gowdy 2012). The term 'natural capital' obscures this crucial difference.

Fifth, issue of collateral, inherent in the monetary definition of capital, helps to highlight a key difference between the assets owned by a capitalist and the labour power owned by a worker. The capitalist can use her assets as collateral and borrow more money to invest in further ventures, hence getting a double usage out of these assets. By contrast, the worker cannot use her labour power as collateral. This illuminates an important aspect of class inequality with capitalism. A major source of capitalism's inequalities of income and wealth becomes capital itself.

Finally, especially after the Great Crash of 2008, it is time for all economists of whatever stripe to reconsider their ideas. Economists have not managed to fit money into their highest most general and most prestigious theory (Hahn 1965, 1987, 1988). Most of academic monetary economics exhibits a 'steadfast refusal to face facts' (Goodhart 2009) or an 'unfortunate uselessness' (Buiter 2009), to quote the words of two leading monetary economists. We need to sweep with a new broom. We should consider using the terminology of capital that prevails in the real business world. Instead of 'capital goods' we may use the broader term 'capital assets', signifying the importance of immaterial or intangible, as well as material, property. Instead of 'human capital' why not 'human resources'? And instead of 'social capital', why not 'networks' or 'social trust'? Capital then becomes more meaningful and special. ${ }^{16}$

\footnotetext{
16 In accord with this view, Piketty (2014) defines capital to include cash, bonds, and shares, collateralizable assets such as buildings, land, machinery, and intellectual property, but excludes social capital and non-slave human capital. With data based on this definition he makes important claims concerning the drivers of economic inequality.
} 
The other option is to leave things as they are. Marxist and mainstream economists may take the view that their approaches are sufficiently robust. But perhaps the time is ripe to question some fundamental terms.

\section{References}

Ahmad, Syed (1991) Capital in Economic Theory: Neo-classical, Cambridge and Chaos (Aldershot: Edward Elgar).

Anonymous (1819) Considerations on the Sinking Fund (London: Hatchard and Son).

Arrow, Kenneth J. (1999) 'Observations on Social Capital', in Dasgupta, Partha and Serageldin, Ismail (eds) (1999) Social Capital: A Multifaceted Perspective (Washington: World Bank), pp. 3-5.

Azzi, Corry and Ehrenberg, Ronald (1975) 'Household Allocation of Time and Church Attendance’, Journal of Political Economy, 38(1), February, pp. 27-56.

Baron, James N. and Hannan, Michael T. (1994) 'The Impact of Economics on Contemporary Sociology’, Journal of Economic Literature, 32(3), September, pp. 1111-46. Reprinted in Swedberg (1996).

Baron, Stephen, Field, John and Schuller, Tom (eds) (2000) Social Capital: Critical Perspectives (Oxford: Oxford University Press).

Becker, Gary S. (1964) Human Capital: A Theoretical Analysis with Special Reference to Education (New York: Columbia University Press).

Becker, Gary S. (1996) Accounting for Tastes (Cambridge, MA: Harvard University Press).

Becker, Gary S. and Murphy, Kevin M. (1988) ‘A Theory of Rational Addiction', Journal of Political Economy, 96(4), pp. 675-700.

Blaug, Mark (1976) 'The Empirical Status of Human Capital Theory: A Slightly Jaundiced Survey’, Journal of Economic Literature, 14(3), September, pp. 827-55.

Böhm-Bawerk, Eugen von (1890) Capital and Interest: A Critical History of Economical Theory, translated from the German text of 1889 by William Smart (London: Macmillan).

Bourdieu, Pierre (1977) Outline of a Theory of Practice, translated by Richard Nice (Cambridge and New York: Cambridge University Press).

Bourdieu, Pierre (1986) 'The Forms of Capital' in John G. Richardson (ed.) Handbook of Theory and Research for the Sociology of Education (New York: Greenwood), pp. 241258.

Bourdieu, Pierre (1988) Homo Academicus (Stanford: Stanford University Press).

Bourdieu, Pierre (1990) The Logic of Practice, translated by Richard Nice from the French edition of 1980 (Stanford and Cambridge: Stanford University Press and Polity Press).

Bowles, Samuel (1999) “'Social Capital” and Community Governance’, Focus: Newsletter for the Institute for Research on Poverty, 20(3), pp. 6-10. 
Braudel, Fernand (1982) Civilization and Capitalism, $15^{\text {th }}-18^{\text {th }}$ Century, Vol. 2, The Wheels of Commerce (London: Collins).

Buiter, Willem H. (2009) 'The Unfortunate Uselessness of Most "State of the Art” Academic Monetary Economics’, Financial Times, 3 March.

http://blogs.ft.com/maverecon/2009/03/the-unfortunate-uselessness-of-most-state-of-theart-academic-monetary-economics/. Retrieved 10 September 2009.

Camic, Charles and Hodgson, Geoffrey M. (eds) (2011) Essential Writings of Thorstein Veblen (London and New York: Routledge).

Cannan, Edwin (1921) 'Early History of the Term Capital', Quarterly Journal of Economics, 35(3), May, pp. 469-481.

Castelfranchi, Cristiano, Falcone, Rino, and Marzo, Francesca (2006) 'Being Trusted in a Social Network: Trust as Relational Capital’, Lecture Notes in Computer Science, 3986, pp. 19-32.

Clark, John Bates (1888) 'Capital and its Earnings', Publications of the American Economic Association, 3(2) May, pp. 9-69.

Cohen, Avi J. (2003) 'The Hayek/Knight Capital Controversy: The Irrelevance of Roundaboutness, or Purging Processes in Time?' History of Political Economy, 35(3), Fall, pp. 469-90.

Cohen, Avi J. and Harcourt, Geoffrey C. (2003) 'Whatever Happened to the Cambridge Capital Theory Controversies?', Journal of Economic Perspectives, 17(1), Winter, pp. 199214.

Coleman, James S. (1988) 'Social Capital in the Creation of Human Capital', American Journal of Sociology, 94(supplement), pp. S95-S120.

Coleman, James S. (1990) Foundations of Social Theory (Cambridge, MA: Harvard University Press).

Dei Ottati, Gabi (1994) 'Trust, Interlinking Transactions and Credit in the Industrial District', Cambridge Journal of Economics, 18(6), December, pp. 529-46.

Donisthorpe, Wordsworth (1880) The Claims of Labour, or, Serfdom, Wagedom, and Freedom (London: Sameul Tinsley).

Ebner, Alexander (2000) 'Schumpeter and the "Schmollerprogramm”: Integrating Theory and History in the Analysis of Economic Development', Journal of Evolutionary Economics,10(3), pp. 355-72.

Edvinsson, Leif and Malone, Michael S. (1997) Intellectual Capital: Realizing Your Company's True Value by Finding its Hidden Brainpower (New York: Harper).

Ellerman, David P. (1992) Property and Contract in Economics: The Case for Economic Democracy (Oxford: Basil Blackwell).

Farr, William (1853) 'The Income and Property Tax', Journal of the Royal Statistical Society, 16(1), March, pp. 1-45.

Fetter, Frank A. (1927) 'Clark's Reformulation of the Capital Concept', in Hollander, Jacob H. (ed.) (1927) Economic Essays Contributed in Honor of John Bates Clark (New York: Macmillan), pp. 136-56. 
Fetter, Frank A. (1930) 'Capital', in Edwin R. A. Seligman and Alvin Johnson (eds) Encyclopaedia of the Social Sciences (New York: Macmillan), Vol. 3, pp. 187-90.

Fine, Ben (2001) Social Capital versus Social Theory: Political Economy and Social Science at the turn of the Millennium (London and New York: Routledge).

Fisher, Irving (1896) 'What is Capital?’ Economic Journal, 6(4), December, pp. 509-534.

Fisher, Irving (1897) 'Senses of “Capital”, Economic Journal, 7(2), June, pp. 199-213.

Fisher, Irving (1904) 'Precedents for Defining Capital', Quarterly Journal of Economics, 18(3), May, pp. 386-408.

Fisher, Irving (1906) The Nature of Capital and Income (New York: Macmillan).

Fisher, Irving (1907) The Rate of Interest: Its Nature, Determination and Relation to Economic Phenomena (New York: Macmillan).

Fox, Alan (1974) Beyond Contract: Work, Power and Trust Relations (London: Faber and Faber).

Goodhart, Charles A. E. (2009) 'The Continuing Muddles of Monetary theory: A Steadfast Refusal to Face Facts’, Economica, 76, October, pp. 821-30.

Grossman, Michael (1972) 'On the Concept of Health Capital and the Demand for Health', Journal of Political Economy, 80(2), March-April, pp. 223-255.

Hahn, Frank H. (1965) 'On Some Problems of Proving the Existence of an Equilibrium in a Monetary Economy’, in Frank H. Hahn and Frank P. R. Brechling (eds) (1965) The Theory of Interest Rates (London: Macmillan), pp. 126-35.

Hahn, Frank H. (1987) ‘The Foundations of Monetary Theory’, in Marcello de Cecco and Jean-Paul Fitoussi (eds) (1987) Monetary Theory and Economic Institutions (London: Macmillan), pp. 21-43.

Hahn, Frank H. (1988) ‘On Monetary Theory’, Economic Journal, 98(4), December, pp. 95773.

Hakim, Catherine (2011) Honey Money: The Power of Erotic Capital (London: Allen Lane).

Hanifan, Lyda J. (1916) 'The Rural School Community Center', Annals of the American Academy of Political and Social Science, 67, pp. 130-8.

Harcourt, Geoffrey C. (1972) Some Cambridge Controversies in the Theory of Capital (Cambridge, Cambridge University Press).

Harris, William (1842) 'Report to the Secretary of the Bombay Government: Slave-Trade of Abyssinia, Embassy to Shoa, etc.' Extracted in The Friend of the Africans, 2 December 1844.

Hartwick, John (1991) 'Degradation of Environmental Capital and National Accounting Procedures’, European Economic Review, 35(2-3), April, pp. 642-9.

Hayek, Friedrich A. (1934) 'On the Relationship between Investment and Output', Economic Journal, 44(2), June, pp. 207-231

Hayek, Friedrich A. (1935b) 'The Maintenance of Capital’, Economica, 2(3), August, pp. 241-276. 
Hayek, Friedrich A. (1936) 'The Mythology of Capital', Quarterly Journal of Economics, 50(2), February, pp. 199-228.

Heinsohn, Gunnar and Steiger, Otto (2013) Ownership Economics: On the Foundations of Interest, Money, Markets, Business Cycles and Economic Development, translated and edited by Frank Decker (London and New York: Routledge).

Hobson, John A. (1926) The Evolution of Modern Capitalism: A Study of Machine Production, revised edn. (London: Walter Scott, and New York: Charles Scribner's).

Hodgson, Geoffrey M. (2001) How Economics Forgot History: The Problem of Historical Specificity in Social Science (London and New York: Routledge).

Hodgson, Geoffrey M. (2003) 'The Enforcement of Contracts and Property Rights: Constitutive versus Epiphenomenal Conceptions of Law', International Review of Sociology,13(2), July, pp. 373-89.

Hodgson, Geoffrey M. (2014) Conceptualizing Capitalism: Institutions, Evolution, Future (Chicago: University of Chicago Press), forthcoming.

Ingham, Geoffrey (2004) The Nature of Money (Cambridge: Polity Press).

Johnson, Alvin S. (1909) Introduction to Economics (Boston: Heath).

Kiker, B. F. (1966) 'The Historical Roots of the Concept of Human Capital', Journal of Political Economy, 74(5), October, pp. 481-99.

Klaes, Matthias (2001) 'Begriffsgeschichte: Between the Scylla of Conceptual and the Charybdis of Institutional History of Economics', Journal of the History of Economic Thought, 23(2), pp. 153-79.

Klein, Benjamin (1988) 'Vertical Integration as Organizational Ownership: The Fisher BodyGeneral Motors Relationship Revisited', Journal of Law, Economics, and Organization, 4(1), Spring, pp. 199-213.

Knies, Karl (1885), Das Geld: Darlegung der Grundlehren von dem Gelde, 2nd ed. (Berlin: Weidmann).

Knight, Frank H. (1934) 'Capital, Time and the Interest Rate', Economica, 1(3), August, pp. 257-286.

Knight, Frank H. (1935) 'Professor Hayek and the Theory of Investment', Economic Journal, 45(1), March, pp. 77-94.

Knorringa, Peter and Irene van Staveren (2007) 'Beyond Social Capital: A Critical Approach’, Review of Social Economy, 65(1), March, pp. 1-9.

Krall, Lisi and Gowdy, John M. (2012) 'An institutional and evolutionary critique of natural capital', in Julien-François Gerber and Rolf Steppacher (eds) (2012) Toward an Integrated Paradigm for Heterodox Economics (London: Palgrave Macmillan), pp. 127-146.

Lindenberg, Siegwart (1993) 'Club hierarchy, social metering and context instruction: governance structures in response to varying self-command capital' in Lindenberg, Siegwart and Schreuder, Hein (eds) (1993) Interdisciplinary Perspectives on Organization Studies (Oxford: Pergamon Press), pp. 195-220.

Marshall, Alfred (1920) Principles of Economics: An Introductory Volume, 8th edn. (London: Macmillan). 
Marx, Karl (1976) Capital, vol. 1, translated from the German edition of 1890 (Harmondsworth: Pelican).

Marx, Karl (1978) Capital, vol. 2, translated from the German edition of 1893 (Harmondsworth: Pelican).

Marx, Karl (1981) Capital, vol. 3, translated from the German edition of 1894 (Harmondsworth: Pelican).

Marx, Karl and Engels, Frederick (1989) Karl Marx and Frederick Engels, Collected Works, Vol. 24, Marx and Engels: 1874-1883 (London: Lawrence and Wishart).

Michaelides, Panayotis G. and Milios, John G. (2009) 'Joseph Schumpeter and the German Historical School’, Cambridge Journal of Economics, 33(3), May, pp. 495-516.

Mill, John Stuart (1848) Principles of Political Economy With Some of Their Applications to Social Philosophy (London: Parker).

Mirowski, Philip (1989) More Heat than Light: Economics as Social Physics, Physics as Nature's Economics (Cambridge and New York: Cambridge University Press).

Mitchell Innes, Alfred (1914) 'The Credit Theory of Money’, Banking Law Journal, 31, December-January, pp. 151-168.

Mouzelis, Nicos (1995) Sociological Theory: What Went Wrong? Diagnosis and Remedies (London and New York: Routledge).

Murray, James A. H. (1893) A New English Dictionary on Historical Principles, Vol. 2 (Oxford: Clarendon Press).

Nietzsche, Friedrich (1996) Human, All Too Human: A Book for Free Spirits, translated from the German edition of 1878 by R. J. Hollingdale (Cambridge and New York: Cambridge University Press).

Nitzan, Jonathan and Bichler, Shimshon (2009) Capital as Power: A Study of Order and Creorder (Abingdon and New York: Routledge).

North, Douglass C. (1971) 'Institutional Change and Economic Growth’, Journal of Economic History, 31(1), March, pp. 118-125.

Oliver, Christine (1997) 'Sustainable Comparative Advantage: Combining Institutional and Resource-Based Views’, Strategic Management Journal, 18(9), October, pp. 697-713.

Olson, Mancur, Jr. (1982) The Rise and Decline of Nations (New Haven: Yale University Press).

Orléan, André (2011) L'empire de la valeur (Paris: La Seuil).

Petty, William (1690) Political Arithmetick (London: Clavel and Mortlock). Reprinted in Charles H. Hull (ed.) (1899) The Economic Writings of Sir William Petty, Vol. 1 (Cambridge: Cambridge University Press).

Piketty, Thomas (2014) Capital in the Twenty-First Century (Cambridge, MA: Belknap Press).

Putnam, Robert D. (1995) 'Tuning In, Tuning Out: The Strange Disappearance of Social Capital in America’, PS: Political Science and Politics, 28(4), pp. 664-83.

Putnam, Robert D. (2000) Bowling Alone: The Collapse and Revival of American Community (New York: Simon and Schuster). 
Renan, Ernest (1899) 'Nation', in Joseph Lalor (ed.) (1899) Cyclopedia of Political Science, Political Economy, and the Political History of the United States (New York: Maynard, Merril).

Rescher, Nicholas (1989) Cognitive Economy: The Economic Dimension of the Theory of Knowledge (Pittsburgh: University of Pittsburgh Press).

Robinson, Joan (1979) Collected Economic Papers - Volume Five (Oxford: Basil Blackwell).

Roscher, Wilhelm (1843) Grundriss zu Vorlesungen über die Staatswirtschaft nach geschichtlicher Methode (Göttingen).

Roscher, Wilhelm (1870) 'Die romantische Schule der Nationalökonomie in Deutschland', Zietschrift für die gesamte Staatswissenschaft, 23.

Samuelson, Paul A. (1976) Economics, $10^{\text {th }}$ edition (New York: McGraw-Hill).

Sandberg, Sveinung and Pedersen, Willy (2009) Street Capital: Black Cannabis Dealers in a White Welfare State (Bristol: Policy Press).

Sandel, Michael (2012) What Money Can't Buy: The Moral Limits of Markets (London: Allen Lane).

Satz, Debra (2010) Why Some Things Should not be for Sale: The Moral Limits of Markets (Oxford and New York: Oxford University Press).

Schultz, Theodore W. (1960) ‘Capital Formation by Education’, Journal of Political Economy,68(4), December, pp. 571-83.

Schultz, Theodore W. (1971) Investment in Human Capital: The Role of Education and of Research (New York: Free Press).

Schultz, Theodore W. (1972) "Human Capital: Policy Issues and Research Opportunities”, in Economic Research: Retrospect and Prospect, Vol 6: Human Resources, (New York: National Bureau of Economic Research), pp. 1-84.

Schumpeter, Joseph A. (1954) History of Economic Analysis (Oxford and New York: Oxford University Press).

Schumpeter, Joseph A. (1956) 'Money and the Social Product', translated from the German edition of 1917 by A. W. Marget, International Economic Papers, No.6, pp.148-211.

Searle, John R. (1995) The Construction of Social Reality (London: Allen Lane).

Senior, Nassau W. (1836) An Outline of the Science of Political Economy (London: Clowes and Sons).

Sik, Endre (1994) 'Network Capital in Capitalist, Communist and Post-Communist Societies', International Contributions to Labour Studies, 4, pp. 73-93.

Smith, Adam (1976) An Inquiry into the Nature and Causes of the Wealth of Nations, 2 vols, originally published 1776, edited by Roy H. Campbell and Andrew S. Skinner (London: Methuen).

Solow, Robert M. (1999) 'Notes on Social Capital and Economic Performance’, in Dasgupta, Partha and Serageldin, Ismail (eds) (1999) Social Capital: A Multifaceted Perspective (Washington: World Bank), pp. 6-10. 
Sombart, Werner (1902) Der moderne Kapitalismus: Historisch-systematische Darstellung des gesamteuropäischen Wirtschaftslebens von seinen Anfängen bis zur Gegenwart, $1^{\text {st }}$ edn., 2 vols (München und Leipzig: Duncker und Humblot).

Sraffa, Piero (1960) Production of Commodities by Means of Commodities: Prelude to a Critique of Economic Theory (Cambridge: Cambridge University Press).

Tomer, John F. (1987) Organizational Capital: The Path to Higher Productivity and WellBeing (New York: Praeger).

Valiente, Wilfredo Santiago (1980) 'Is Frank Knight the Victor in the Controversy between the Two Cambridges?’ History of Political Economy, 12(1), pp. 41-64.

Veblen, Thorstein B. (1892) ‘Böhm-Bawerk’s Definition of Capital and the Source of Wages', Quarterly Journal of Economics, 6, pp. 247-52. Reprinted in Camic and Hodgson (2011).

Veblen, Thorstein B. (1901) 'Industrial and Pecuniary Employments', Publications of the American Economic Association, Series 3, 2(1), February, pp. 190-235. Reprinted in Camic and Hodgson (2011).

Veblen, Thorstein B. (1908a) 'Professor Clark’s Economics', Quarterly Journal of Economics, 22(2), February, pp. 147-95. Reprinted in Camic and Hodgson (2011).

Veblen, Thorstein B. (1908b) 'Fisher’s Capital and Income’, Political Science Quarterly, 23(1), March, pp. 112-128. Reprinted in Camic and Hodgson (2011).

Veblen, Thorstein B. (1908c) 'On the Nature of Capital I: The Productivity of Capital Goods', Quarterly Journal of Economics, 22(4), August, pp. 517-42. Reprinted in Camic and Hodgson (2011).

Veblen, Thorstein B. (1908d) 'On the Nature of Capital II: Investment, Intangible Assets, and the Pecuniary Magnate’, Quarterly Journal of Economics, 23(1), November, pp. 104-136. Reprinted in Camic and Hodgson (2011).

Veljanovski, C. G. and Whelan, C. J. (1983) 'Professional Negligence and the Quality of Legal Services. An Economic Perspective’, Modern Law Review, 46(6), November, pp. 700-718.

Verter, Bradford (2003) 'Spiritual Capital: Theorizing Religion with Bourdieu against Bourdieu’, Sociological Theory, 21(2), June, pp. 150-174.

Walzer, Michael (1983) Spheres of Justice: A Defence of Pluralism and Equality (New York: Basic Books).

Weber, Max (1968) Economy and Society: An Outline of Interpretative Sociology, 2 vols, translated from the German edition of 1921-1922 by G. Roth and C. Wittich (Berkeley: University of California Press).

Westgarth, William (1875) The Science of Capital and Money: With Prefatory Remarks on Commercial and Financial Crises in their Past and Present Features, and on Paper Issues and the Bank Act (London: T. W. Nicholson). 